\title{
Evaluation of Insecticides for the Management of Diamondback Moth, (Plutella xylostella (L.) (Lepidoptera: Plutellidae) on Cabbage under Field Condition
}

\author{
Teshome Tolessa (MSc.) $* 1 \quad$ Tekle Lombamo (MSc.) $* 2 \quad$ Silas Chiko (MSc.) $* 3$ \\ 1.Ambo University, School of Graduate Studies College of Agriculture and Veterinary Sciences Department of \\ Plant sciences, PO box 307, Ambo, Ethiopia \\ 2.Wolaita Sodo University, College of Agriculture, Department of Plant Science P.O. Box 01, Wolaita Sodo, \\ Ethiopia
}

\begin{abstract}
Diamondback Moth (DBM) is one of the major constraints for the profitable production of cabbage in the country as well as Ambo highlands in particular. The field study was conducted to evaluate the susceptible varietal resistance of cabbage (Brassica oleracea var.capitata) against diamondback moth (DBM) (Plutella xylostella) infestations and damages at the Ambo university farm in a relay cropping (Rain season) in 2019. Varietal resistance was compared with conventional spraying using Randomized complete block design (RCBD) spraying chemical of insecticides at different spray interval. The Cabbage varieties were Copenhagen from local market. Sampling was done by weekly counting of larvae and pupae, and scoring pest damage on six randomly selected plants per plot for 5 weeks from the third week after transplanting. The number of damage and undamaged cabbage heads were counted on all plants per plot at maturity stage. Results showed that sprayed and unsprayed plots had significantly $(\mathrm{P}<0.05)$ different numbers of DBM stages (larvae and pupae). The yield losses of cabbage caused by DBM could reach up to more than $80 \%$ as several infestations occurred in the field. Due to this problem, farmers in Ambo highlands are preferred to apply the broad spectrum of non-systematic insecticides rather than implementing other pest management strategies. The demand for insecticides in Ambo highlands seems endless until today, but more aggressive. This paper highlighted the possibility of implementing intercropping cabbage with six treatments in reducing pupae and larvae populations of DBM in the polyculture system. The distributions of pupae and larvae population of DBM against the factors of temperature and rainfall also have been addressed in this study. A total of six treatments were indicated, that including Cutter, Trigger, Ethiozenon, Nomax, Fastac and Control which arranged in (RCBD). The result indicated that nonsignificant variations $(\mathrm{P}<0.05)$ were observed among the population of pupae and larvae at all seven treatments tested compared with the control. Moreover, pupae and larvae of DBM were negatively correlated with temperature and rainfall factors. The results also showed that a critical period of DBM infestations was detected in the preheading stage $(<30 \mathrm{DAT})$. In terms of performance among treatments, our finding also has shown that Nomax was the best treatment acted as a repellent.
\end{abstract}

Keywords: Diamondback Moth, Management Strategies, (Plutella xylostella ) Insecticide Resistance.

DOI: $10.7176 / \mathrm{JBAH} / 11-23-04$

Publication date: December $31^{\text {st }} 2021$

\section{Introduction}

Cabbage, both head and kale, is the second most important vegetable crop in Ethiopia both in area coverage and as well as level of production next to red pepper, Capsicum spp. (Moa 2002). It is among the major vegetables produced by private farmers 3.4 million hectares were grown worldwide (FAOSTAT, 2012) and the state farms in Ethiopia (Lemma et al., 1994). Land allotted for kale cabbage alone in the main rainy season (Maher) is estimated to be 14, 528 ha with a production level of 143,680 tons (Moa, 2002). Between 1993 and 2009 the global area of Brassica vegetable crops increased by 39\%, and in 2009 an estimated concomitant with this change was an intensification of farming practices, with cabbage yields increasing by $27 \%$, and Brassica vegetables now contribute more than US\$26 billion to the world economy. Over the same period, the area of oilseed rape planted increased by 59\%, and in 2009 more than 31 million hectares were cultivated worldwide (FAOSTAT, 2012), often in regions where the crop was not previously grown. These changes have resulted in considerable modifications to many local landscapes (Furlong et al., 2008) and provide revised challenges for DBM management (Schell horn et al., 2008).

A number of insect species including the diamondback moth (DBM), Plutella xylostellaL. (Lepidoptera: Plutellidae), cabbage aphid Brevicoryne brassicae (L.) (Homoptera: Aphididae), mustard aphid Lipaphiserysimi Kaltenbach (Homoptera: Aphidian), flea beetles Phylloterta sp. and cabbage leaf miner Chromatom yiahorticola Goureau (Dipteral: Agromyzidae) inflict damage on brassica crops in Ethiopia (Tsedeke and Gashaw beza, 1994). As in any of the tropical countries, the severity of damage inflicted by DBM on cabbage is higher than other insect pests (Talker and Shelton, 1993). Diamondback moth (DBM) (Plutella xylostellaL., (Lepidoptera: 
Plutellidae) is one of the most serious pest of cruciferous crops and causes huge economic losses of more than 1 billion US dollars in terms of annual management costs (Talker, 1992; Talker and Shelton, 1993). It occurs wherever crucifers are grown, and is believed to be the most universally distributed of all Lepidoptera (Merick, 1928), especially in tropical and sub-tropical regions. The amount of damage varies greatly, depending on plant growth stage, larval densities and size. Larval feeding causes typical symptoms in the form of shot holes of irregular shape in the leaves. If larvae are numerous they may eat the entire leaf, leaving only the veins and causing more than 90\% crop loss (Verk GMM Trek and Wright, 1996). It is a serious pest as it feeds on the marketable portion of the plant, the (leaves of cabbage and other leafy brassicas); only a few fourth stage larvae on a cabbage can make it un-saleable (Shelton et al., 1983; Malta is et al., 1998). A recent study (Saluki et al., 2012) estimated that annual DBM control in Brassica vegetable crops alone costs US\$1.4 billion worldwide, rising to US\$2.7 billion if yield losses are included and to \$4-5 billion if DBM losses and control costs to the worldwide canola industry are added.

DBM is one of the few insect species that has developed field resistance to all major classes of insecticides like and is ranked second in the Arthropod Pesticide Resistance Database (APRD) for the highest number of insecticides with reported resistance in at least one population (APRD, 2012). The gap or the Statement of the problem of this research is the yield of cabbage has decreased due to diamond back moth, the quality of cabbage has also reduced due to diamond back moth, DMB has developed résistance to many insecticides, and the management options available are very limited. Therefore, selecting insecticides which are environmentally friendly is crucial. Therefore, this study was designed with the objectives of scaling up production and productivity through evaluation of some selected insectside efficacy to reduce DBM.

\section{Materials and Methods \\ Description of the Study Area}

The experiment was conducted at field and green house station of Ambo farm research center during 2019. Ambo Town is located $120 \mathrm{~km}$ west of Addis Ababa at $8^{0} 98^{\prime}$ South latitudes and $37^{0} 83^{\prime}$ North longitudes. The Annual rainfall ranges from $900-1100 \mathrm{~mm}$ an average of $1000 \mathrm{~mm}$ with the minimum Temperatures means ranging from $10-27 \mathrm{C}^{0}$ for the maximum with an average of $18 \mathrm{c}^{0}$ and altitude ranging from $1380-3300$ m.a.s.l.

\section{The Experimental Site and Experimental Design}

The experimental design of field trials consisted of Randomized Complete Block Design (RCBD) with six treatments and four replications i.e. there is possibility of treatment combinations (Cabbage of Copenhagen + Cutter), (Cabbage of Copenhagen + Trigger), (Cabbage of Copenhagen + Ethiozinon), (Cabbage of Copenhagen + Nomax), (Cabbage of Copenhagen + fastac), (only Cabbage of Copenhagen as Control). Each block was divided into six raised beds. The size of each unit of raised bed was $1.5 \mathrm{~m} * 3 \mathrm{~m}\left(4.5 \mathrm{~m}^{2}\right)$ of spacing between $50 \mathrm{~cm} * 50 \mathrm{~cm}$ both plant and rows respectively. The DBM seedlings were transplanted at the four true leaves stage (30 days after sowing). A $0.5 \mathrm{~m}$ wide unplanted alley left between each plot to avoid spray drift between adjacent plots. A separate 20L capacity knapsack sprayer was used to apply each for the treatment solution to the point of runoff including underside of the leaves. Applications were recommended at 69 days after transplanting of seedlings. Insect present was assessed in weekly on 6 plants from the random from each row. Infestation by B. brassica were scored and harvested or the plants in each plot were used for yield and insect damage assessment. In other case all agronomic practices like weeding and fertilizer were applied as recommended.

\section{Insecticide Application and Spraying Schedule}

All treatments were sprayed with insecticides using the agricultural knapsack sprayer (Model PB-20) with a tank capacity of 20 liters. Insecticides were sprayed starting at seedling stage until late heading stage. Applications were commenced 1-2 month after transplanting of seedlings and were continued on weekly bases thereafter.

\section{Data Collected}

The type of cabbage worm (DBM), sowing and harvesting dates, date of spraying, plant height (cm), number of larvae and pupa, plot yield were recorded. In addition, description of the farm and locality including altitudes, field history, field size and environmental conditions like monthly rain fall were also recorded. Harvested Cabbage was categorized as clean marketable and unmarketable if it had symptoms of damage of insect infestation was seen. The weight of marketable and unmarketable was recorded separately. The mean number of Cabbage per plant was assessed in each plot.

\section{Yield Loss Estimation}

The relative yield loss in each treatment was determined by percent of that of Cabbage per plots of the experiment. Yield Losses were calculated separately for each of the treatment and yield component of the cabbage were determined as a percent of that of the protected plots and yield losses were calculated based on 
formula:

$$
R L \%=\frac{(Y 1-Y 2)}{Y_{1}} \times 100
$$

Where, RL- relative loss (reduction of the parameters yield and yield components), Y1- mean of the respective parameters on protected plot (plots with maximum protection) and $\mathrm{Y} 2$-mean of the respective parameters in unprotected plots (untreated plots).

\section{Cost Benefit Analysis}

Cost benefit analysis is a quantitative analytical tool used to find out how resources are allocated gain over the whole project life (Belli et al., 1998). It is determined using the mathematical expression given in according to the following. The deference between treatments, the option economic data was subjected to analysis using the partial budget analysis method (CIMMYT, 1988). Marginal rate return was calculated using the following formula:

$$
\begin{gathered}
\text { MRR }(\%)=\frac{\mathrm{DNI}}{\mathrm{DIC}} \quad 100 . \text { Where, MRR is marginal rate of returns, DNI is Deference in net income } \\
\text { compared with control, DIC is difference in input Cost compared to control. }
\end{gathered}
$$

\section{Data Analysis}

Data on insecticide parameters (plant growth and yield components, yield loss and cost benefit analysis were subjected to analysis of variance (ANOVA) using (SAS) version 9.0 software (SAS Institute, 2002). Fisher's protected least significant difference (LSD) values were used to separate differences among treatment means $(\mathrm{P} \leq$ 0.05) for the field assessment of cabbage DBM and change in plant growth and yield components (dependent variables). Mean cabbage head weight was analyzed using ANOVA and SNK test. The proportion of cabbage heads in each plot with damaged and undamaged were analyzed using generalized linear model with a binomial distribution and logit link.

\section{Result and Discussion \\ Effects of Insecticide Application on DBM}

The different insecticides were sprayed to respective plots sown cabbage at every seven days interval so that to evaluate the effectiveness of each insecticide against DBM as follows; Cutter (Emamectin benzoate 48gm/lt+Acetamipride 64gm/lt), Trigger (Lambda Cyhalothrin (50g/ltEC), Fastac (alphaCypermethrime), Nomax (Teflubenzuron $(150 \mathrm{Sc})$ and Ethio-zinon (Diazinon $(600 \mathrm{gm} / \mathrm{l})$ consecutively. The chemicals were formulated based on the recommendation written down on the containers of each pesticide by the Companies. Further information on the application, amount of formulation and specification of each pesticides used were

\begin{tabular}{|c|c|c|c|c|c|}
\hline No. & $\begin{array}{l}\text { Insecticide (Trade } \\
\text { name) }\end{array}$ & Common name & Company & $\begin{array}{l}\text { (Recommendation) } \\
\text { Dosage/ha }\end{array}$ & $\begin{array}{l}\text { (Recommendation) } \\
\text { Dosage/ha }\end{array}$ \\
\hline 1. & Fastac (100g/lEC) & $\begin{array}{l}\text { alpha-Cypermethrime } \\
\text { (10gm/1 E C) }\end{array}$ & BASF & $\begin{array}{l}150-300 \mathrm{ml} / 10001 \mathrm{t} \\
\text { of } \mathrm{H}_{2} \mathrm{O} / \mathrm{ha}\end{array}$ & $\begin{array}{l}150-300 \mathrm{ml} / 1000 \mathrm{lt} \\
\text { of } \mathrm{H}_{2} 0 / \mathrm{ha}\end{array}$ \\
\hline 2. & Trigger(5 EC) & $\begin{array}{l}\text { Lambda-Cyhalothrin } \\
(50 \mathrm{~g} / 1 \mathrm{t} \mathrm{EC})\end{array}$ & Agrisher & $800-1500 \mathrm{ml} / \mathrm{ha}$ & $800-1500 \mathrm{ml} / \mathrm{ha}$ \\
\hline 3. & Ethiozinon $(600 \mathrm{gm} / 1)$ & Diazinon ( $60 \%$ E C) & $\begin{array}{l}\text { Adami } \\
\text { Tulu } \\
\text { Pesticide } \\
\text { Company }\end{array}$ & $1-2$ lt/ha & $1-2$ lt/ha \\
\hline 4. & Nomax $(150 \mathrm{Sc})$ & $\begin{array}{l}\text { Teflubenzuron } \\
(150 \mathrm{gm} / \mathrm{lt} \mathrm{EC})\end{array}$ & BASF & $0.25-0.31 \mathrm{t} / \mathrm{ha}$ & $0.25-0.31 \mathrm{t} / \mathrm{ha}$ \\
\hline 5. & Cutter(112 E C) & $\begin{array}{l}\text { Emamectin benzoate } \\
48 \mathrm{gm} / \mathrm{lt}+\text { Acetamipride } \\
64 \mathrm{gm} / \mathrm{lt}\end{array}$ & Agrisher & $0.31 \mathrm{t} / \mathrm{ha}$ & $0.31 \mathrm{t} / \mathrm{ha}$ \\
\hline 6. & Untreated & Control & - & - & - \\
\hline
\end{tabular}
presented clearly on (Table 1 ).

Table 1 Different Insecticide Application of Spray interval at per hector of treatment

Effect of Spraying Interval on Diamond Back Moth

Application of treatment (dosage) of $(0.54 \mathrm{ml})$ of Cutter for four (4) plots by the addition of thousand (10001t) of water with mixed $0.54 \mathrm{ml}$ of Cutter. The spray of Cutter per plot was $0.135 \mathrm{ml}$. But, in general the application of Cutter on block (replication)/plot-1 for replication -1, plot-7 for replication-2, plot-14 for replication-3, \& plot- 
21 for replication-4.The application of Trigger (dosage/treatment was $2.07 \mathrm{ml}$ ) to four (4) plots by the same water (10001t) of mixed with Trigger. The spray of Trigger per plot was $0.520 \mathrm{ml}$. But, in general the application of Trigger on the replication or block/plot. Plot-2 for replication-1, plot-8 for replication-2, plot-18 for replication-3 \& plot-22 for replication-4. The application of dosage/treatment of Ethionenon was $2.7 \mathrm{ml}$ to the four (4) plots of mixing (10001t) water with Ethiozenon. The spray of Ethioninon per plot was $0.675 \mathrm{ml}$. But, in general the application of Ethiozenon plot per replication. Plot-3 for replication-1, plot-9 for replication-2, plot-17 for replication-3 \& plot-24 for replication-4. The application of dosage/treatment of Nomax is $0.54 \mathrm{ml}$ to the four (4) plots mixed with (10001t) water with Nomax. The spray of Nomax per plot was $0.135 \mathrm{ml}$ in general the application of Nomax replication of plot-4 for replication-1, plot-10 for replication-2, plot-13 for replication-3 and plot-20 for replication-4. The application of dosage/treatment of Fastac was $0.405 \mathrm{ml}$ to the four (4) plots of the mixed (1000lt) of water with Fastac. The spray of Fastac per plot was $0.101 \mathrm{ml}$. in general the application of Fastac replication per plot. Plot (5) for replication-1, plot-11 for repplication-2, plot-16 for repplication-3 \& plot19 for repplication-4.and the control one was on replication-1 was plot number-6, on replication- 2 was plot number-12, on replication-3 was plot number-15 \& on replication- 4 was plot number-23 as shown in (Table 2 ).

Table 2. Different treatment Dosages at 4 replication of Application.

\begin{tabular}{llllll}
\hline $\begin{array}{l}\text { Treatment } \\
\text { number }\end{array}$ & Trade name & $\begin{array}{l}\text { Dose/Trt (for } \\
\text { Application }\end{array}$ & reps.) & Dose/plot $(\mathrm{ml})$ & $\begin{array}{l}\text { Frequency } \\
\text { application }\end{array}$ \\
\hline 1 & Fastac 100EC & $0.405 \mathrm{ml}$ & 0.101 & Every7 day \\
2 & Trigger 5EC & $2.07 \mathrm{ml}$ & 0.520 & Every14 days \\
3 & Ethiozinon $60 \%$ & $2.7 \mathrm{ml}$ & 0.675 & $10-14$ days \\
4 & Nomax 150Sc & $0.54 \mathrm{ml}$ & 0.135 & $1-4$ weeks \\
5 & Cutter 112Ec & $0.54 \mathrm{ml}$ & 0.135 & $7-10$ days \\
6 & Control & - & - & - \\
\hline \hline
\end{tabular}

\section{Application of treatment on the plot in four replication}

For a treatment the application of all treatment on each plot of four replications was the same. When we apply the treatment on the rep-1 was down the slope, on rep-2 upward, on rep-3 down the slope and on rep-4 upward. It is W-shape or zigzag line of the spray interval. On plot one T1 was applied, on plot two T2 was applied, on plot three T3 was applied, on plot four T4 was applied, on plot five T5 was applied and the control left without application. On replication two the application of treatments in each plot was the same with the application of treatments on replication one. But, on replication three the application of treatment on each plot was not the same. The application of treatment number four was on plot number thirteen, the application of treatment number one was on plot number fourteen, plot number six was the control. The application treatment number five was on plot number sixteen, the application of treatment number three was on plot number seventeen, and the application of treatment number two was on plot number eighteen. The application of treatment number three was on plot number twenty-four, there is no application of treatment number six on plot number twenty-three, the application of treatment number two was on plot number twenty-two, the application of treatment number one was on plot number twenty-one, the application of treatment number four was on plot number twenty, the application of treatment number five was on plot number nineteen.

Table 3 Application of each treatment per plot within replication.

\begin{tabular}{|c|c|c|c|c|c|c|c|c|c|}
\hline No & $\begin{array}{l}\text { Trade } \\
\text { name }\end{array}$ & $\begin{array}{l}\text { Number } \\
\text { of } \\
\text { Treatment }\end{array}$ & $\begin{array}{l}\text { Plot } \\
\text { Number }\end{array}$ & $\begin{array}{l}\text { Number } \\
\text { of } \\
\text { Treatment }\end{array}$ & $\begin{array}{l}\text { Plot } \\
\text { Number }\end{array}$ & $\begin{array}{l}\text { Number } \\
\text { of } \\
\text { Treatment }\end{array}$ & $\begin{array}{l}\text { Plot } \\
\text { Number }\end{array}$ & $\begin{array}{l}\text { Number } \\
\text { of } \\
\text { Treatment }\end{array}$ & $\begin{array}{l}\text { Plot } \\
\text { Number }\end{array}$ \\
\hline 1. & Cutter & 1 & 1 & 1 & 7 & 2 & 18 & 5 & 19 \\
\hline 2. & Trigger & 2 & 2 & 2 & 8 & 3 & 17 & 4 & 20 \\
\hline 3. & Ethiozinon & 3 & 3 & 3 & 9 & 5 & 16 & 1 & 21 \\
\hline 4. & Nomax & 4 & 4 & 4 & 10 & 6 & 15 & 2 & 22 \\
\hline 5. & Fastac & 5 & 5 & 5 & 11 & 1 & 14 & 6 & 23 \\
\hline 6. & Control & 6 & 6 & 6 & 12 & 4 & 13 & 3 & 24 \\
\hline & & \multicolumn{2}{|c|}{ R-1 } & \multicolumn{2}{|c|}{ R-2 } & \multicolumn{2}{|c|}{$\mathrm{R}-3$} & \multicolumn{2}{|c|}{ R-4 } \\
\hline
\end{tabular}

Plant growth and yield component

The effect of different Insecticides on the plant height and head weight of cabbage

On the analysis of plant height and Mean of head weight of cabbage at significant difference of P- value at (0.05), there was no significant difference between plant height among the treatments, but significant difference among the treatments on the damage crop of the Mean of head weight of cabbage. Application of Nomax in (100g) was more damaged as compared with other treatments. There were significant differences with Fastac, Ethiozenon, 
Trigger, Cutter and the Control one. But, the control was highly damaged $(2.75 \mathrm{~g})$ as compared with the other treatments. But, when we compared the undamaged one Ethiozenon $(1320.2 \mathrm{~g})$ is highly control than the other treatment the least control one is the untreated $(580.2 \mathrm{~g})$. On the other hand, the treatment among each other there is significant difference. The largest control one is highly significant with Fastac, Cutter, Control, and Trigger \& Nomax (Table 4).

Table 4 The effect of different insecticide on the plant height and head weight of cabbage.

\begin{tabular}{|c|c|c|c|}
\hline \multirow[b]{2}{*}{ Treatments } & \multirow[b]{2}{*}{ Plant height (cm) } & \multicolumn{2}{|c|}{ Mean of head weight of cabbage (gm) } \\
\hline & & Damage (gm) & Undamaged (gm) \\
\hline Cutter & $32.75 \mathrm{a}$ & $18.75 d^{*}$ & $806.2 \mathrm{bc} *$ \\
\hline Trigger & $33.04 \mathrm{a}$ & $22.5 \mathrm{~d}^{*}$ & $1020.6 \mathrm{abc} *$ \\
\hline Ethiozenon & $33.21 \mathrm{a}$ & $30 c^{*}$ & $1320.2 \mathrm{a}^{* *}$ \\
\hline Nomax & $32.29 \mathrm{a}$ & $100 \mathrm{a}^{* *}$ & $1095.6 \mathrm{ab}^{*}$ \\
\hline Fastac & $32.54 \mathrm{a}$ & $60 b^{*}$ & $784 b c *$ \\
\hline Control & $31.33 \mathrm{a}$ & $2.75 \mathrm{e}^{*}$ & $580.2 c^{*}$ \\
\hline CV $(\%)$ & 6.82 & 10.20 & 31.37 \\
\hline $\operatorname{LSD}(0.05)$ & Ns & 4.90 & 360.71 \\
\hline Mean & 32.53 & 39 & 934.47 \\
\hline
\end{tabular}

$\mathrm{Ns}=$ non-significant,${ }^{*}=$ significant, ${ }^{* *}=$ highly significant, $\mathrm{LSD}=$ least significant difference, $\mathrm{CV}=$ coefficient of variation, the letters with the same values are not significant difference.

\section{Yield loss Estimation}

On the yield loss estimation there is significant difference among the treatment application on variety of the Copenhagen for each plot. Application of Nomax in $(100 \mathrm{~g})$ is more damage as compared with other treatment. There is significant difference with Fastac, Ethiozenon, Trigger, Cutter and the Control one. But, the highly damage Control one $(2.75 \mathrm{~g})$ as compared with the highest damage. Comparing were the undamaged one Ethiozenon $(1320.2 \mathrm{~g})$ is highly control than the other treatment the least control one is the untreated $(580.2 \mathrm{~g})$. When we compared the treatment among each other there is significant difference. The largest control one is highly significant with Fastac, Cutter, Control, and Trigger \& Nomax.

\section{The Percent of Relative Yield loss}

On the treatment of Cutter are $(38.93 \%)$, treatment of Trigger is $(22.73 \%)$, treatment of Ethiozenon are $(0 \%)$, treatment of Nomax is $(17.03 \%)$, treatment of Fastac is $40.62 \%)$, and (the untreated one is $(56.05 \%)$ which can compared the damage and undamaged yield loss. 
Table 5 The effect of different insecticide on the head weight of cabbage.

\begin{tabular}{llll}
\hline \hline Treatments & \multicolumn{2}{c}{ Yield loss } \\
\cline { 2 - 3 } Cutter & Damage $(\mathrm{gm})$ & Undamaged $(\mathrm{gm})$ & Relative yield loss $(\%)$ \\
Trigger & $18.75 \mathrm{~d}^{*}$ & $806.2 \mathrm{bc} *$ & 38.93 \\
Ethiozenon & $22.5 \mathrm{~d}^{*}$ & $1020.6 \mathrm{bac}$ & 22.73 \\
Nomax & $30 \mathrm{c}^{*}$ & $1320.2 \mathrm{a}^{* *}$ & 0.00 \\
Fastac & $100 \mathrm{a}^{* *}$ & $1095.6 \mathrm{ba} \mathrm{a}^{*}$ & 17.03 \\
Control & $60 \mathrm{~b}^{*}$ & & 40.62 \\
CV (\%) & $2.75 \mathrm{e}^{*}$ & $784 \mathrm{bc} *$ & 56.05 \\
LSD (0.05) & 10.20 & $580.2 \mathrm{c}^{*}$ & - \\
Mean & 4.90 & 31.37 & - \\
\hline \hline
\end{tabular}

$\mathrm{LSD}=$ least significant difference, $\mathrm{CV}=$ Coefficient of variation, the letters with the same values are not Significant difference.

\section{Cost Benefit Analysis}

The paramers of Cabbage yield/ha on the treatment value is significant different. Ethiozinon $(28,844)$ is the highest value than the other treatment \& The Control (15244) one is the least Value than the other treatment. It is highly Significant among each other as compared the rest value. As shown in (Table 5). When we compared Ethiozinone means values are $(28,844)$ with Nomax $(26,177)$ it is significant difference but, when we compared the other treatment like Fastac $(24,666)$, cutter $(23,200)$ and Trigger $(20,888)$ highly significant. On Cabbage yield (birr $/ \mathrm{kg}$ ) there is no significant diffirence among the treatment value (9.5). The Total Cabbage sale (birr/ha) among the treatment is highly significant value. Ethiozinon $(274,018)$ is the highest value than the other treatment. When we compared with Nomax $(248,682)$ it is highly significant as compared among the treatment. The least value among the treatment is the Control $(144,818)$ one. The Input $\&$ labor cost among the treatment significantly difference values. The highest value among the treatment is Nomax $(13,400)$ as compared the other treatment significant different. The least value is the control $(12,400)$ one. On Marginal Cost value is significant difference among the treatment. Nomax $(3,400)$ is the highest value than the other treatment and it is significant difference among in each the treatment. The least value is the control one among the treatment. The Net benefit values are highly Significant among the each treatment. Ethiozinon is the highest value than the other treatment. The least value of among the treatment is the control. The Marginal benefit values are highly Significant among the each treatment. Ethiozinon is the highly significant than the other treatment. The least value of among the treatments is Control. The Marginal rates of return value are highly significant difference among the treatment. Ethiozinon is the highest value and highly significant difference among the treatment. The least value of among the treatment is the control one.

Table 6. Different parameters of Cost Benefit Analysis in different treatment value

\begin{tabular}{|c|c|c|c|c|c|c|c|}
\hline \multirow[t]{2}{*}{ parameters } & \multirow[t]{2}{*}{ Unit } & \multicolumn{6}{|c|}{ Treatments } \\
\hline & & Cutter & Trigger & Ethiozinon & Nomax & Fastac & Control \\
\hline Cabbage yield/ha & $\mathrm{kg}$ & 23,200 & 20,888 & 28,844 & 26,177 & 24,666 & 15,244 \\
\hline $\begin{array}{l}\text { Cabbage } \quad \text { yield } \\
\text { (birr/kg) }\end{array}$ & birr & 9.5 & 9.5 & 9.5 & 9.5 & 9.5 & 9.5 \\
\hline $\begin{array}{l}\text { Total Cabbage sale } \\
\text { (birr/ha) }\end{array}$ & birr & 220,400 & 198,436 & 274,018 & 248,682 & 234,327 & 144,818 \\
\hline Input \& labor cost & birr & 13,000 & 12,900 & 12,625 & 13,400 & 13,100 & 12,400 \\
\hline Marginal Cost & birr & 3,000 & 2,900 & 2,625 & 3,400 & 3,100 & 2,400 \\
\hline Net benefit & birr & 207,400 & $1,85,536$ & $2,61,393$ & 235,282 & 221,227 & 132,418 \\
\hline Marginal benefit & birr & 195,000 & $1,73,136$ & $2,48,993$ & 222,882 & 208,827 & 120,018 \\
\hline $\begin{array}{l}\text { Marginal rate of } \\
\text { return }\end{array}$ & birr & 6,500 & 5970 & 9485 & 6555 & 6736 & 5000 \\
\hline
\end{tabular}




\section{The effect of different application of insecticide on cabbage DBM growth stage}

The data analysis for larvae and pupae assessment at the first round (DAT 69) was indicated no significance difference especially in pupae and larvae mortality rate among treatments except significantly difference between Fastac and Ethiozenon in larvae mortality(Table 7). The number of small larvae per 6 plants ranged from 0.7 to 1.83 at the pre count through the 69 days after treatment (DAT). Larger -sized larvae ranged from 0.8 to 1.7 larvae per 6 plants at 3 DAT then increased to range as high as 1.83 larvae per 6 plants after 7 DAT. In the second round (DAT 78) was indicated no significance difference among the treatment in egg, larvae and pupae mortality rate.except Significant difference in Fastac and Ethiozenon in egg mortality. There is significant diffirence in each treatment except the means with the same letter in Larvae mortality and it also the significant difference among treatment with the Control. At significant diffirence of Cutter, Trigger and Fastac in a pupae mortality. In the third round of (DAT (85) of egg, larvae and pupae was indicated significant difference among the treatment. In each treatment of Cutter, Trigger, Ethiozenon, Fastac and Control is significant diffirence in egg mortality rate. Except, means with the same letter in each treatment. There is significant diffirence among the treatment as compared with Control in the mortality rate of larvae. Among the treatment there is significant differences are their in Trigger, Ethiozenon, Nomax, Fastac, and Control except cutter. In the pupae mortality there is significant diffirence among the treatment Cutter with trigger and trigger with Nomax and Fastac. In the four rounds (DAT (92) there is no significant diffirence among the treatment except Trigger and Control in Larvae mortality rate and in pupae mortality rate Trigger and Nomax is significant diffirence among each other. At the Last five rounds (DAT (99) are no significant. Difference among the treatment except Cutter, Trigger, Ethiozenon and Fastac in egg mortality rate. The others Larvae and pupae mortality rate are significant difference among the treatment with Control.

Table7. The effect of different application of insecticide on cabbage DBM growth stage

\begin{tabular}{|c|c|c|c|c|c|c|c|c|c|c|c|c|c|c|}
\hline \multirow[t]{2}{*}{ Treatments } & \multicolumn{2}{|c|}{$\begin{array}{l}1^{\text {st }} \text { round } \\
\text { DAT (69) }\end{array}$} & \multicolumn{3}{|c|}{$\begin{array}{l}2^{\text {nd }} \text { round } \\
\text { DAT (78) }\end{array}$} & \multicolumn{3}{|c|}{$\begin{array}{l}3^{\text {rd }} \text { round } \\
\text { DAT (85) }\end{array}$} & \multicolumn{3}{|c|}{$\begin{array}{l}4^{\text {th }} \text { round } \\
\text { DAT (92) }\end{array}$} & \multicolumn{3}{|c|}{$\begin{array}{l}5^{\text {th }} \text { round } \\
\text { DAT (99) }\end{array}$} \\
\hline & larvae & pupae & egg & larvae & pupae & egg & larvae & pupae & egg & larvae & pupae & Egg & larvae & pupae \\
\hline Cutter & $1.7 \mathrm{ab}$ & $0.54 a$ & $0.17 \mathrm{ab}$ & $0.83 \mathrm{c}$ & $0.75 \mathrm{c}$ & $0.17 \mathrm{a}$ & $0.8 b c$ & $0.75 \mathrm{c}$ & $0.23 \mathrm{a}$ & $0.21 \mathrm{~cd}$ & $0.96 \mathrm{ab}$ & $0.05 \mathrm{c}$ & $0.21 \mathrm{~b}$ & $0.54 b$ \\
\hline Trigger & $0.8 \mathrm{ab}$ & $0.33 \mathrm{a}$ & $0.1 b c$ & $0.75 c$ & $1.29 \mathrm{a}$ & $0.09 \mathrm{~b}$ & $0.75 c$ & $1.29 \mathrm{a}$ & $0.21 a$ & $0.13 \mathrm{~d}$ & $1.00 \mathrm{a}$ & $0.15 b$ & $0.1 b$ & $0.58 b$ \\
\hline Ethiozenon & $0.71 b$ & $0.54 a$ & $0.09 \mathrm{c}$ & $1.04 b$ & $1.08 \mathrm{ab}$ & $0.09 \mathrm{~b}$ & $1.04 b$ & $1.08 \mathrm{ab}$ & $0.24 a$ & $0.3 a b c$ & $0.9 a b c$ & $0.25 \mathrm{a}$ & $0.18 b$ & $0.54 b$ \\
\hline Nomax & $1.5 \mathrm{ab}$ & $0.25 \mathrm{a}$ & $0.13 a b c$ & $0.42 \mathrm{~d}$ & $0.8 b c$ & $.13 a b$ & $0.42 \mathrm{~d}$ & $0.8 b c$ & $0.23 \mathrm{a}$ & $0.3 \mathrm{bcd}$ & $0.63 \mathrm{c}$ & $0.2 a b$ & $0.12 b$ & $0.42 b$ \\
\hline Fastac & $1.83 \mathrm{a}$ & 0.71a & $0.18 \mathrm{a}$ & $1.04 b$ & $0.75 \mathrm{c}$ & $0.17 \mathrm{a}$ & $0.46 \mathrm{~d}$ & $0.79 \mathrm{c}$ & $0.22 \mathrm{a}$ & $0.38 \mathrm{ab}$ & $0.71 b c$ & $0.15 b$ & $0.18 b$ & $0.55 b$ \\
\hline Control & $1.4 a b$ & $0.54 a$ & $0.1 b c$ & $1.54 \mathrm{a}$ & $0.87 b c$ & $0.09 \mathrm{~b}$ & $1.96 \mathrm{a}$ & $0.87 b c$ & $0.24 a$ & $0.42 a$ & $0.96 \mathrm{ab}$ & $0.2 \mathrm{ab}$ & $0.84 a$ & $0.92 \mathrm{a}$ \\
\hline CV (\%) & 22.48 & 25.64 & 36.86 & 15.0 & 20.1 & 25.86 & 18.24 & 19.21 & 25.44 & 34.09 & 21.03 & 29.79 & 34.44 & 34.89 \\
\hline $\operatorname{LSD}(0.05)$ & 0.45 & NS & 0.07 & 0.17 & 0.33 & 0.18 & 0.65 & 0.93 & NS & 0.119 & 0.22 & 0.08 & 0.114 & 0.25 \\
\hline Mean & 1.32 & 0.49 & 0.13 & 0.84 & 0.93 & 0.13 & 0.84 & 0.93 & 0.23 & 0.28 & 0.85 & 0.17 & 0.27 & 0.59 \\
\hline
\end{tabular}

$\mathrm{Ns}=$ non-Significant, $\mathrm{LSD}=$ least significant difference, $\mathrm{CV}=$ coefficient of variation, the means with the same letters are not significant difference. DAT=Days after transplanting.

\section{CONCLUSION AND RECOMMENDATION}

\section{Conclusion}

The result from evaluation of insecticide on the management of Cabbage of diamond back moth in Ambo agricultural Farm research center showed that, diamond back moth was with high infestation on cabbage. The different insecticides were sprayed to respective plots sown cabbage at every seven days interval so that to evaluate the effectiveness of each insecticide against diamond back moth. The chemicals were formulated based on the recommendation written down on the containers of each pesticide by the Companies. The effect of Spraying interval on diamond back moth was the application of treatments (dosage) of $(0.54 \mathrm{ml})$ of Cutter to four (4) plots by the addition of thousand (1000lt) of water with mixed $0.54 \mathrm{ml}$ of Cutter solution. The spray of Cutter per plot was $0.135 \mathrm{ml}$. For one treatment the application of all treatment on each plots of four replications was the same. The effect of different insecticide on the plant height and head weight of cabbage was no significant difference between plant heights among the treatments. But, significant difference among the treatments on the damaged crop of the Mean of head weight of cabbage.

\section{Recommendation}

The farmers should use such a recommended insecticides to increase the cabbage production and productivity as well as to control the diamond back moth effectively chemicals like Trigger, Cutter, Ethiozinon, Nomax and Fastac.

REFERENCE

Abbott, W. S. 1925. A method of computing the effectiveness of an insecticide. 
Entomology, 18:265-267. Arthropod pesticides resistance Database (APRD).2012.East Lansing: Michigan state univ.http://WWW Pesticide resistance.com/index.php.

Asman, K., B. Ekbom and B. Ramert. 2001. Effect of intercropping on oviposition and Emigration behavior of the leek moth (Lepidoptera: Acrolepiidae) and the diamondback moth (Le pidoptera:Plutellidae). Environ. Entomol. 30:288-294.

Belay Beyene (2007).Studies on the effect of inter cropping and application of livestock manure on the infestation \&damage of Kale by Diamondback moth, plutella xylostella (L.) in abio.farm unpublished Msc. thesis, Addis university, Addis Ababa, Ethiopia.

Belli, P., Anderson J., Barnum H., Dixon J.andTan J. P. 1998. Handbook on Economic Analysis of Investment Operations, Operational core services network learning and leadership centere.Washington, DC: the World Bank

Bhalla, O.P \& Dubey, J.K.(2006).Bionomics of Diamondback moth in the northwestern Himalaya Nauni,Solan,Indian Journal of Agricultural Research 6:56-59.

Buranday, R. P and R.S. Raros, 1975. Effects of Cabbage-tomato intercropping on the incidence and Oviposition of the diamond back moth plutella xylotella (L.).

Phillippines Entomologist.2 (5):369-374.

Capinera, J.L.2001. Handbook of Vegetable pests. Academic press, New York.pp.729. Hort. Sci. 25:1643-46.

Dover, J. W. 1986.The effect of labiates herbs and white clover on plutellaxylostella oviposition. Entomol. Exp. Appl.39:177-182.

Eigenbrode, S.D. and A.M.Shelton, 1990. Behavior of neonate diamond back moth larvae (Lepidoptera: Plutellidae) on gloss-leaved resistant genotypes of Brassicsa oleracea. Evironmental Entomology. 19:566571.

Eigenbrode, S. D., and J. T. Trumble. 1994. Host-plant resistance to insects in integrated pest-Management in Vegetable crops. J.Agric. Entomol.11:201-224.

Eigenbrode, S. D., S. Moodie, and T. Castagnola. 1995. Predators mediate host plant resistance to a phytophagous pest in cabbage with glossy leaf wax. Entomol.Exp. Appl. 77:335-342.

Ender by, N.and Rid land, P. (1996).Diamondback moth state of Victoria. Department of primary industry, Victoria, Journal of Entomology 12:56-66.

Facknath, S. (1997).Integrating pest Management of plutella xylostella, an important pest of Crucifers in Mauritius. AMAS (Food and Agricultural Research council), Reduit: University of Mauritius. Journal of Entomology 7:103-108.

Food and Agricultural Organization (FAO) (2000).Inter country program for the development and application of IPM in vegetable growing in south east Africa. Pesticide in cabbage IPM: An Ecological Guide. Vientiane, Lao, PP.7-55.

Food and Agriculture Organization Statistics (FAOSTAT), 2007. United Nations. http:// faostat.fao. Org. April $22,2013$.

FAO STAT.2012.production statistics. Rome:FAO.http://faostat.fao.org/site/567/default. Aspx \# ancor April 22, 2013.

Furlong MJ, Shi ZH, Liu SS, ZaluckiMP.2004.Evaluation of the impact of natural enemies on plutella xylostella L.(Lepidoptera:Yponomeutidae) populations on commercial Brassica farms. Agric.For. Entomol.6:311-22.

Furlong MJ, spattered H, Rid Land PM Enders by NM, Edwards OR, and et.al., 2008. Ecology of diamond back moth in Aust. J.Exp.Agric.48:1494-505.

FurlongMJ, ZaluckiMP. 2010. Exploiting predators for pest management: the need for sound ecological assessment.Entomol.Exp.Appl.135:225-36.

Furlong MJ., Denis J. Wright and Lloyd M. Dosdall. 2013. Diamondback moth Ecology and Management: Problems, progress, and prospects. Annual Review of Entomology. 58:517-541.

Gashaw beza Ayalew and c.K.p.O. Ogol, 2006.Occurrence of the diamond back moth (plutella xylostella L.) and its parasitoids in Ethiopia influence of geographical region \&agronomic traits. Journal of Applied Entomology.130 (6-7):343-348.

Grzywacz, D., Rossbach, A., Rauf, A., Russell, D. A., Srinivasan, R. and Shelton, A. M. 2010. Current control methods for diamondback moth and other brassica insect pests and the prospects for improved management with lepidopteran-105 Resistant Bt vegetable brassicas in Asia and Africa. Crop Protection, 29: 68-79.

Harcourt D. G., 1957.Biology of diamondback moth, plutella maculipennis (Curt.) (Lepidoptera: plutellidae) in Eastern Ontario. II. Life-history, behavior and host relationship. Canadian Entomologist, 89:554-564.

Harvey CT, Eubanks MD. 2005. Intraguild predation of parasitoids by Solenopsis invicta: a non-disruptive interaction. Entomology.Exp.Appl. 114:127-35.

Henry Doubleday Tropical Advisory Service (HDRA), 2000. Pest Control TCP3 Diamondback moth. Coventry, UK, pp.3.

Henry, K\&Baker, G. (2008).Diamondback moth in canola, (SARDI) south Australian Research \& development 
Institute) August, 2008 3:2-5.

Ignacimuthu, S. (2004). Green pesticides for insect pest management, Meeting reports, Current Science No. 8, 25 April 2004. Pp. 86

Ivey, P., and S. Johnson. 1998. Integrating control tactics for managing cabbage looper (Lepidoptera:Noctuidae) and diamondback moth (Lepidoptera:Yponomeutidae) on Cabbage.Trop. Agric.75:369-374.

Javier, E, Q., 1992-Foreword. In:Talekar, N.S.(ed.), The Management of Diamond back moth \& other Crucifer pests, proceeding of the Second international Workshop, 10-14 Dec.1990, Tainan,Taiwan.Asian vegetable Research Development center publication 92-368, Taipei, 603pp. Katz, Solomon H. and Weaver, William Ways (2003). Encyclopedia of Food and Culture 2. Scribner. ISBN 978-0-684-80565-8.

Kfir, R., 2003. Biological control of the diamond back moth plutella xylostella in Africa.In:

Neuenschwander, p., Borgemeister, C., Langward, J. (Eds.), Biological control in IPM Systems in Africa. CABI Publishing, Wallingford, UK, pp. 363-375.

Lemman Dessalegne, E. Hearth, Temesgen Belehun, B.Lemaga and seyfu Geberemariam, 1994. Horticultural Research-past, present and future trends. pp1928. In: E., Hearth and L.

Dessalegne (eds).proceedings of the second National Horticultural Workshop, Addis, Ababa,Ethiopia,1-3 December 1992, IAR/FAO.

Latheef, M. A., and R. D. Irwin. 1983. Seasonal abundance and parasitism of lepidopterous larvae on Brassica green in Virginia. J. Ga. Entomol. Soc. 18: 164-168.

Lim, G. S. (1992). Integrated pest management of DBM; practical reality. In: Diamondback moth and other crucifer pests, $\mathrm{pp} .565-576$, (Talekar, N.S.eds), Proceeding of the $2^{\text {nd }}$ International Workshop, Asian Vegetable Research and Development Center, Tania, Taiwan.

Lohr B, Gichini G, Rossbach A,Nyambo B.2008.After-release dispersal of Diadegma semiclausum. control in intensively-sprayed crucifer production in north-eastern Thailand. See Ref. 161, pp. 97-102.

Verkerk R.H.J. \& Wright D.J. 1996. Multitrophic interaction and management of the diamondback moth: Are view. Bulletin of Entomological Research, 86:205-216.

Zalucki MP, Shabbir A, Silva R, Adamson D, Liu SS, Furlong MJ. 2012. Estimating the economic cost of one of the World's major insect pests, plutella xylostella: Just how long is a piece of string J. Econ. Entomol. 105:1115-29 